Publisher: GSA

Journal: GEOL: Geology

DOI:10.1130/G38935.1

Data Repository item 2017158

doi:10.1130/G38935.1

Manuscript received 22 September 2016

Revised manuscript received 26 January 2017

Manuscript accepted 29 January 2017

Printed in USA

\title{
The fate of sediment, wood, and organic carbon eroded during an extreme flood, Colorado Front Range, USA
}

\author{
S.L Rathburn' ${ }^{1}$, G.L. Bennett ${ }^{1,2}$, E.E. Wohl ${ }^{1}$, C. Briles ${ }^{3}$, B. McElroy ${ }^{4}$, and N. Sutfin ${ }^{1}$ \\ ${ }^{1}$ Department of Geosciences, Campus Delivery 1482, Colorado State University, Fort \\ Collins, Colorado 80523-1482, USA \\ ${ }^{2}$ U.S. Forest Service, Rocky Mountain Research Station, 240 Prospect Road, Fort Col- \\ lins, Colorado 80526, USA \\ ${ }^{3}$ Department of Geography and Environmental Sciences, Campus Box 172, University of \\ Colorado Denver, Denver, Colorado 80217-3364, USA \\ ${ }^{4}$ Department of Geology and Geophysics, Department 3006, University of Wyoming, \\ Laramie, Wyoming 82071, USA
}

\begin{abstract}
Identifying and quantifying the dominant processes of erosion and tracking the fate of sediment, wood, and carbon eroded during floods is important for understanding channel response to floods, downstream sediment and carbon loading, and the influence of extreme events on landscapes and the terrestrial carbon cycle. We quantify sediment, wood, and organic carbon (OC) from source to local sink following an extreme flood in
\end{abstract}


Publisher: GSA

Journal: GEOL: Geology

DOI:10.1130/G38935.1

the tectonically quiescent, semiarid Colorado (USA) Front Range. Erosion of $>500,000$

$\mathrm{m}^{3}$ or as much as $\sim 115 \mathrm{yr}$ of weathering products occurred through landsliding and channel erosion during September 2013 flooding. More than half of the eroded sediment was deposited at the inlet and delta of a water supply reservoir, resulting in the equivalent of $100 \mathrm{yr}$ of reservoir sedimentation and $2 \%$ loss in water storage capacity. The flood discharged $28 \mathrm{Mg} \mathrm{C} / \mathrm{km}^{2}$, producing an event OC flux equivalent to humid, tectonically active areas. Post-flood remobilization resulted in a further $\sim 100 \mathrm{yr}$ of reservoir sedimentation plus export of an additional $1.3 \mathrm{Mg} \mathrm{C} / \mathrm{km}^{2}$ of wood, demonstrating the ongoing impact of the flood on reservoir capacity and carbon cycling. Pronounced channel widening during the flood created accommodation space for $40 \%$ of flood sediment and storage of wood and eroded carbon. We conclude that confined channels, normally dismissed as transport reaches, can store and export substantial amounts of flood constituents.

\section{INTRODUCTION}

Extreme floods in mountainous regions typically coincide with mass movements through intense precipitation. This combination profoundly alters hillslopes, riparian areas, and channel geometry, and introduces large volumes of sediment, wood, and nutrients such as organic carbon (OC) into rivers. Identifying and quantifying the magnitudes and processes of erosion of sediment, wood, and OC from hillslopes and channels and tracking the fates of flood constituents through budgeting are important for understanding channel response to floods, as well as for informing management and restoration.

Budgets for fluvial materials can also be used to create context for short-term, small-scale measurements of mass fluxes, particularly during episodic extreme events, and to understand the relative importance of diverse local sources and sinks at varying 
Publisher: GSA

Journal: GEOL: Geology

DOI:10.1130/G38935.1

time and space scales. Mass budgets thus form a vital part of studies of the critical zone, yet they rarely combine the triad of sediment, wood, and carbon. Existing studies of sediment and/or wood-derived fluxes come from tropical and/or tectonically active regions (e.g., Hilton et al., 2008; Wohl and Ogden, 2013). Mountainous mid-latitude regions have been highlighted as hotspots of OC accumulation (Schimel and Braswell, 2005), yet we lack details of OC dynamics for these regions (e.g., Smith et al., 2001), particularly with respect to the significance of extreme events to OC fluxes and partitioning of OC fluxes into sediment and wood.

We present an integrated sediment, wood, and OC budget derived from a semiarid, tectonically quiescent catchment in the southern Rocky Mountains (western USA) that underwent an extreme rainstorm and associated hillslope failures and flooding in September 2013. The Ralph Price Reservoir at the lower end of North St. Vrain Creek (NSV) in the Colorado Front Range allows us to develop a source-to-sink budget of sediment, wood, and OC fluxes during the 2013 storm. Unlike other canyons in the Front Range where extensive post-flood sediment and wood removal occurred, no unquantified postflood clearance was carried out along NSV Creek, thus it provides an ideal setting to document the immediate and ongoing effects of the flood. We quantify fluxes of sediment, wood, and carbon within the catchment during the 2013 event and quantify postflood remobilization to understand the fate of flood-derived constituents and the processes of continued downstream transport and loading to the reservoir. Fluxes during and after the extreme disturbance are then compared to decadal and long-term average rates from the study area to assess the significance of the event geomorphically and for the terrestrial carbon cycle. 
Publisher: GSA

Journal: GEOL: Geology

DOI:10.1130/G38935.1

\section{STUDY SITE AND METHODS}

NSV Creek is underlain by Precambrian granite and biotite schist (Braddock and Cole, 1990) and drains the east side of the Continental Divide in northern Colorado (Fig. 1). The mountainous portion of NSV Creek has cascade, step-pool, or riffle-run morphology formed in cobble to boulder-size sediment. Valley geometry varies longitudinally, although the study reach is laterally confined, with the valley bottom generally less than eight times the bankfull channel width. A $15 \mathrm{~km}$ reach of NSV Creek is bounded upstream by a low-gradient beaver meadow where 2013 flood effects were minimal (overbank deposition of sand and gravel; Wohl et al., 2017) and downstream by Ralph Price Reservoir where the trapping efficiency for sediment $(>0.63 \mathrm{~mm})$, wood, and OC is effectively $100 \%$. As it enters the reservoir, NSV Creek is $\sim 15 \mathrm{~m}$ wide and drains $245 \mathrm{~km}^{2}$. The upper basin is within Rocky Mountain National Park and a city preserve and has undergone minimal logging, land development, or flow regulation.

From 9-15 September 2013, a large tropical storm produced $>350 \mathrm{~mm}$ of precipitation (Gochis et al., 2015), generating a >200 yr flood (Yochum, 2015) that swept through towns along the base of the Front Range, causing multiple deaths and extensive damage to infrastructure. Peak flood discharge measured through the spillway of Ralph

Price Reservoir was estimated as $280 \mathrm{~m}^{3} / \mathrm{s}$ (K. Huson, 2013, personal commun.; mean annual peak flow of $20 \mathrm{~m}^{3} / \mathrm{s}$; Wohl et al., 2004). This discharge was sustained for at least a day following peak rainfall intensity. Abundant landslides stripped hillslopes in the NSV (Coe et al., 2014; Rengers et al., 2016). Erosion by landsliding of hundreds to thousands of years of hillslope weathering projects was determined in basins to the south (Anderson et al., 2015), but our study is the first (of which we are aware) to quantify the 
Publisher: GSA

Journal: GEOL: Geology

DOI:10.1130/G38935.1

fate of the eroded sediment, along with wood and carbon, and to document the ongoing implications for reservoir storage and carbon cycling.

A combination of field work and analysis of remotely sensed data was used to quantify sediment, wood, and OC budgets along a $15 \mathrm{~km}$ reach $\left(100 \mathrm{~km}^{2}\right)$ of NSV Creek upstream from the reservoir in which rainfall and flood effects were concentrated (Fig. 1A). We quantified flood-derived sediment, wood, and OC inputs (I) and outputs (O) and compared these to stored volumes $(\Delta S)$, using the simple budget equation $\mathrm{I}-\mathrm{O}=\Delta \mathrm{S}$, where O is sediment, wood, and carbon delivered to Ralph Price Reservoir. No flushing of sediment, wood, and associated OC has occurred since dam closure in May 1969, allowing us to compare flood and post-flood sedimentation rates with decadal rates prior to the flood.

\section{Sediment Input, Output, and Storage}

Inputs of sediment were quantified through a digital elevation model (DEM) of difference (DoD) produced from 2011 (pre-flood) and 2013 (post-flood) lidar-derived DEMs with Geomorphic Change Detection (GCD) software (Wheaton et al., 2010). We identified a minimum level of detection as 2 standard deviations of elevation change in areas with no expected change, setting a threshold of $\pm 0.34 \mathrm{~m}$ for the DoD. We mapped the aerial extent of landslides initiated during the 2013 storm as well as processes of channel erosion and deposition and performed a budget segregation with GCD to associate volumes of erosion and deposition with these different processes. Volumetric uncertainty associated with the $0.34 \mathrm{~m}$ threshold is propagated into the sediment budget and typically ranges from $7 \%$ to $40 \%$ for a particular geomorphic unit. 
Publisher: GSA

Journal: GEOL: Geology

DOI:10.1130/G38935.1

We quantified output sediment volume at the reservoir inlet from the $\mathrm{DoD}$, along with repeat ground-based topographic surveys. We quantified sediment deposited in the reservoir delta by differencing sonar bathymetry collected in March 2014 and preimpoundment topography. We determined the flood contribution of sedimentation in the delta from a reservoir core (Fig. 1E) collected after the flood that showed clear flood and pre-flood stratigraphy, as well as through extensive probing of delta sediment to determine representative aggradation over the broader delta area. The core was collected from the distal portion of the delta toe where large lateral variability in sediment composition is unlikely.

Remobilization of sediment along the approach channel during snowmelt 2014 was quantified using field surveys. Horizontal and vertical error averaged $1-6 \mathrm{~cm}$ and $6-$ $9 \mathrm{~cm}$, respectively. We collected another reservoir core in 2016 (Fig. 1E) to quantify additional contributions to the delta following $2 \mathrm{yr}$ of above-average snowmelt runoff in 2014 and 2016.

\section{Wood Input, Output, and Storage}

We quantified wood input from the area of floodplain erosion estimated from the DoD. We applied an average volume of wood per area, $V=234 \mathrm{~m}^{3} / \mathrm{ha}$, calculated from undisturbed sections of the riparian corridor using $V=A H \rho$, where $A$ is mean trunk basal area, $H$ is mean tree height, and $\rho$ is mean stem density. Hillslope input of wood is considered negligible because the hillslopes affected by landsliding were not heavily vegetated pre-flood (Rengers et al., 2016). Wood output at the reservoir inlet was based on an 
Publisher: GSA

Journal: GEOL: Geology

DOI:10.1130/G38935.1

estimate of wood removed by contractors following the flood (Fig. DR1 in the GSA Data Repository $\left.^{1}\right)$.

\section{OC Input, Output, and Storage}

Organic carbon addressed herein is that within sediment eroded from hillslopes and riparian areas distinguished as soil, litter, and large wood, and organic material analyzed in core sediment collected from the reservoir delta. Input of carbon is based on area of disturbance estimated by lidar differencing and on values of carbon in soil, litter, and above-ground biomass of 85, 30, and $100 \mathrm{Mg} \mathrm{C} / \mathrm{ha}$, respectively (DeLuca and Aplet, 2008). These values are representative of montane, fire-maintained, ponderosa pine forests with a stand age of $\sim 100 \mathrm{yr}$ (DeLuca and Aplet, 2008), accurately describing our study area.

\section{RESULTS}

\section{Flood Sediment, Wood, and Carbon Budget}

More than $500,000 \mathrm{~m}^{3}$ of sediment were eroded in the flood with nearly equal inputs from hillslope and channel erosion (Fig. 2; Table DR1). Landsliding dominated hillslope erosion, with 108 landslides $\left(10-23,000 \mathrm{~m}^{3}\right)$ eroding a volume of $218,000 \mathrm{~m}^{3}$, or $43 \%$ of the total flood eroded volume. Tributary channels contributed a further 152,400 $\mathrm{m}^{3}(30 \%)$ of sediment. Erosion along the trunk channel accounted for the remaining $135,500 \mathrm{~m}^{3}(27 \%)$ of flood eroded sediment, with lateral erosion through processes of bend adjustment (widening without avulsion) and bank erosion accounting for $97 \%$ of the total (Figs. 1B and 3).

${ }^{1}$ GSA Data Repository item 2017158, tabulated sediment, wood, and carbon volumes; pre- and post-flood sediment yields and carbon loading; total organic carbon compared to extreme events worldwide (with Figures DR1-DR7 of reservoir core and ${ }^{210} \mathrm{~Pb}$ ages); electrical resistivity and ground-penetrating radar results; and grain size analyses, is available online at http://www.geosociety.org/datarepository/2017/ or on request from editing@geosociety.org. 
Publisher: GSA

Journal: GEOL: Geology

DOI:10.1130/G38935.1

Approximately $60 \%\left(298,200 \mathrm{~m}^{3}\right)$ of eroded sediment was discharged into the reservoir; $\sim 50 \%\left(258,200 \mathrm{~m}^{3}\right)$ was deposited in the inlet, forming a new approach channel (Figs. 1C and 1E), and an additional 10\% $\left(31,000 \mathrm{~m}^{3}\right)$ of sediment was deposited within the reservoir delta based on a comparison of post-flood reservoir bathymetry with pre-dam topography and sediment core. Summing inlet and delta sediment deposition indicates a loss of total water storage capacity of $\sim 2 \%$.

The remaining $\sim 40 \%$ of flood-eroded sediment $\left(222,000 \mathrm{~m}^{3}\right)$ was deposited in the catchment upstream from the reservoir (Fig. 1B), predominantly within the accommodation space created by lateral erosion across the valley bottom or at the scoured toes of hillslopes in highly confined reaches. Flood erosion of the NSV channel occupied the entire width of the valley along $\sim 90 \%$ of the study reach (Fig. DR2). We observe a strong correlation between sediment aggradation and channel widening (Fig. 3). The greatest widening and sediment aggradation were associated with the processes of bend adjustment and avulsions, which were in turn associated with large wood accumulation in the channel that possibly caused log jams (Fig. 3; Figs. DR2 and DR3B).

The difference between sediment input $\left(507,800 \mathrm{~m}^{3}\right)$ and output $\left(298,200 \mathrm{~m}^{3}\right)$ plus storage $\left(222,000 \mathrm{~m}^{3}\right)$ produces a discrepancy of only $12,400 \mathrm{~m}^{3}$ in our budget, allowing us to account for the fate of $98 \%$ of total eroded sediment (Fig. 2; Table DR1). It is likely that the missing $2 \%$ is due to large amounts of unquantified suspended sediment in the reservoir, evident in post-flood images (Fig. 1E). Therefore, the budget is a minimum estimate of loading to the reservoir.

Lateral erosion of the floodplain input $6200 \mathrm{~m}^{3}$ of wood. This is nearly balanced by $4300 \mathrm{~m}^{3}$ of wood that was removed after the flood from a large floating jam in the res- 
Publisher: GSA

Journal: GEOL: Geology

DOI:10.1130/G38935.1

ervoir (Figs. 1E and 2; Fig. DR1). We estimate that $2000 \mathrm{~m}^{3}$ wood remains stored in sediment in the new reservoir approach channel and within log jams in the upper catchment (Table DR1).

Approximately $7300 \mathrm{Mg} \mathrm{C}$ eroded during the flood, with $2200 \mathrm{Mg} \mathrm{C}$ as soil OC from channels and hillslopes, and $5100 \mathrm{Mg} \mathrm{C}$ stripped from the channel corridor as wood, litter, and soil carbon (Table DR1). Organic carbon deposited in the reservoir was estimated as $2800 \mathrm{Mg} \mathrm{C}$, with $1100 \mathrm{Mg} \mathrm{C}$ of this deposited as wood in a large log jam at mouth of the reservoir (Fig. 1E) and the remainder as fine organic matter in the reservoir delta. We treat the OC component in the budget as an order of magnitude approximation.

\section{Long-Term Significance of the Flood Geologically and for the Carbon Cycle}

The flood resulted in a lowering of $3.4 \mathrm{~mm}$ averaged over the $100 \mathrm{~km}^{2}$ area of lidar analysis (Table DR2); this is $\sim 57-115 \times$ greater than cosmogenic nuclide erosion rates for the region of $0.03-0.06 \mathrm{~mm} / \mathrm{yr}$ (Dethier et al., 2014). We estimate that a minimum of 420 mm of flood sedimentation occurred within Ralph Price Reservoir, nearly 100x greater than the $5.4 \mathrm{~mm} / \mathrm{yr}$ background sedimentation rate over the $44 \mathrm{yr}$ life of the dam.

The flood carbon yield of $28 \mathrm{Mg} \mathrm{C} / \mathrm{km}^{2}$ was $\sim 50 \times$ greater than pre-flood carbon yield of $0.5 \mathrm{Mg} \mathrm{C} / \mathrm{km}^{2}$ (Table DR3).

\section{Post-flood Remobilization}

Snowmelt runoff in 2014 resulted in $3 \mathrm{~m}$ of channel incision of unconsolidated flood deposits in the reservoir approach channel (Figs. DR5 and DR6), remobilizing $41,000 \mathrm{~m}^{3}$ of sediment into the reservoir delta (Fig. 2; Table DR1). A further $1.30 \mathrm{Mg}$ $\mathrm{C} / \mathrm{km}^{2}$ was remobilized into the reservoir as large wood, equivalent to a further $21 \mathrm{yr}$ of carbon loading based on pre-flood carbon yield. 
Publisher: GSA

Journal: GEOL: Geology

DOI:10.1130/G38935.1

\section{DISCUSSION}

We document the fate of sediment, wood, and carbon in a highly flood-affected catchment in the Colorado Front Range. The 2013 flood caused 57-115 yr of erosion and $100 \mathrm{yr}$ of reservoir sedimentation. Notably, the $5.4 \mathrm{~mm} / \mathrm{yr}$ pre-flood sedimentation rate is comparable to modern post-fire erosion rates from burned areas of similar elevation in Colorado (Moody and Martin, 2001). High decadal rates of sedimentation likely reflect the crystalline geology and location of the study reach downstream from a knickzone formed by rapid incision of rivers through the softer sediment of the Front Range piedmont (Anderson et al., 2015).

NSV flooding produced $28 \mathrm{Mg} \mathrm{C} / \mathrm{km}^{2}$ through erosion of soil carbon, litter, and wood. This value is comparable, on an order of magnitude, to estimates of storm-derived carbon in wetter and/or tectonically active areas (Table DR3). High-OC storm inputs into NSV Creek are likely related to a longer storm recurrence interval and extensive lateral channel erosion that denuded valley bottom OC in soils, litter, and riparian vegetation. Post-flood wood removed from the reservoir was identified primarily as riparian in origin. Furthermore, recovery of hillslope weathering products, riparian vegetation, and overbank sediment deposition, the basis for reestablishing pre-flood carbon stocks, will take much longer along NSV Creek than for tropical counterparts, and may be $\sim 10^{2}-10^{3}$ yr.

Although flood yields of sediment and carbon (particularly as wood) were very high for the NSV catchment both historically and in comparison to extreme events elsewhere, much eroded material remains stored in the catchment in the accommodation space created through pronounced channel widening. The stored sediment represents an- 
Publisher: GSA

Journal: GEOL: Geology

DOI:10.1130/G38935.1

other potential $1 \%$ loss of total water storage capacity within the reservoir. Our results indicate that many flood-affected Front Range rivers store, and therefore will export, sediment, wood, and carbon for years to come, posing ongoing challenges to downstream communities and reservoirs and with implications for carbon cycling on lower order streams that make up a majority of stream length. Continued high discharges may result in disproportionate transport of coarse particulate organic matter (Turowski et al., 2016). In a disturbance context, confined channels have long been treated as transport reaches (Montgomery, 1999). A flood-induced change in channel confinement, however, brings new focus to flood-affected confined channels regionally and to rivers worldwide that function as important post-flood source areas.

\section{CONCLUSIONS}

We developed an integrated sediment, wood, and organic carbon (OC) budget from source to anthropogenic sink following an extreme flood in the Colorado Front Range through a combination of lidar differencing, reservoir surveying, and coring. Extensive landsliding and channel erosion during September 2013 flooding transformed the reservoir inlet into an approach channel, deposited $\sim 100 \mathrm{yr}$ of sediment into the reservoir, accounting for $\sim 2 \%$ loss in capacity, and produced an OC flux equivalent to those documented in more humid, tectonically active areas. Approximately $40 \%$ of flood sediments remain stored in the upper catchment, predominantly within accommodation space created by flood-induced channel widening. Post-flood snow melt remobilized and redeposited a flood-equivalent volume of sediment from the approach channel to the reservoir. Our results indicate that many flood-affected Front Range rivers will export sediment, wood, and carbon for years to come, posing ongoing challenges for water-supply management, 
Publisher: GSA

Journal: GEOL: Geology

DOI:10.1130/G38935.1

with implications for terrestrial carbon cycling. Although confined rivers function as

dominantly transport reaches, pronounced channel widening during extreme events may accommodate sediment storage and switch these channels to post-flood source areas.

\section{ACKNOWLEDGMENTS}

Funding was provided through National Science Foundation award EAR-1410472 and the Gladys Cole Memorial Fund (Quaternary Geology and Geomorphology Division, Geological Society of America). We thank the numerous people who helped in the field, laboratory, and with data analysis. Jon Major and two anonymous reviewers helped clarify the text.

\section{REFERENCES CITED}

Anderson, S.W., Anderson, S.P., and Anderson, R.S., 2015, Exhumation by debris flows in the 2013 Colorado Front Range Storm: Geology, v. 43, p. 391-394, doi:10.1130/G36507.1.

Braddock, W.A., and Cole, J.S., 1990, Geologic map of Rocky Mountain National Park and vicinity, Colorado: U.S. Geological Survey Miscellaneous Investigations Series Map I-1973, scale 1:50,000.

Coe, J.A., Kean, J.W., Godt, J.W., Baum, R.L., Jones, E.S., Gochis, D.J., and Anderson, G.S., 2014, New insights into debris-flow hazards from an extraordinary event in the Colorado Front Range: GSA Today, v. 24, p. 4-10, doi:10.1130/GSATG214A.1.

DeLuca, T., and Aplet, G., 2008, Charcoal and carbon storage in forest soils of the Rocky Mountain west: Frontiers in Ecology and the Environment, v. 6, p. 18-24, doi:10.1890/070070. 
Publisher: GSA

Journal: GEOL: Geology

DOI:10.1130/G38935.1

Dethier, D., Ouimet, W., Bierman, P., Rood, D., and Balco, G., 2014, Basins and bedrock: Spatial variation in ${ }^{10} \mathrm{Be}$ erosion rates and increasing relief in the southern Rocky Mountains, USA: Geology, v. 42, p. 167-170, doi:10.1130/G34922.1.

Fryirs, K., and Brierley, G., 2001, Variability in sediment delivery and storage along river courses in Bega catchment, NSW, Australia: Implications for geomorphic river recovery: Geomorphology, v. 38, p. 237-265, doi:10.1016/S0169-555X(00)00093-3.

Gochis, D., Schumacher, R., Friedrich, K., Doesken, N., Kelsch, M., Sun, J., Ikeda, K., Lindsey, D., Wood, A., and Dolan, B., 2015, The great Colorado flood of September 2013: American Meteorological Society Bulletin, v. 96, p. 1461-1487, doi:10.1175/BAMS-D-13-00241.1.

Hilton, R.G., Galy, A., and Hovius, N., 2008, Riverine particulate organic carbon from an active mountain belt: Importance of landslides: Global Biogeochemical Cycles, v. 22, GB1017, doi:10.1029/2006GB002905.

Montgomery, D., 1999, Process domains and the river continuum: American Water Resources Association Journal, v. 35, p. 397-410, doi:10.1111/j.17521688.1999.tb03598.x.

Moody, J., and Martin, D., 2001, Initial hydrologic and geomorphic response following a wildfire in the Colorado Front Range: Earth Surface Processes and Landforms, v. 26, p. 1049-1070, doi:10.1002/esp.253.

Rengers, F.K., McGuire, L.A., Coe, J.A., Kean, J.W., Baum, R.L., Staley, D.M., and Godt, J.W., 2016, The influence of vegetation on debris-flow initiation during extreme rainfall in the northern Colorado Front Range: Geology, v. 44, p. 823-826, doi:10.1130/G38096.1. 
Publisher: GSA

Journal: GEOL: Geology

DOI:10.1130/G38935.1

Schimel, D., and Braswell, B.H., 2005, The role of mid-latitude mountains in the carbon cycle: Global perspective and a western US case study, in Huber, U.M., et al., eds., Global change and mountain regions: Amsterdam, Springer, p. 449-456, doi:10.1007/1-4020-3508-X_45.

Smith, S.V., Renwick, W.H., Buddemeier, R.W., and Crossland, C.J., 2001, Budgets of soil erosion and deposition for sediments and sedimentary organic carbon across the conterminous United States: Global Biogeochemical Cycles, v. 15, p. 697-707, doi:10.1029/2000GB001341.

Turowski, J., Hilton, R., and Sparkes, R., 2016, Decadal carbon discharge by a mountain stream is dominated by coarse organic matter: Geology, v. 44, p. 27-30, doi:10.1130/G37192.1.

Wheaton, J.M., Brasington, J., Darby, S.E., and Sear, D.A., 2010, Accounting for uncertainty in DEMs from repeat topographic surveys: Improved sediment budgets: Earth Surface Processes and Landforms, v. 35, p. 136-156, doi:10.1002/esp.1886.

Wohl, E., and Ogden, F., 2013, Organic carbon export in the form of wood during an extreme tropical storm, upper Rio Chagres, Panama: Earth Surface Processes and Landforms, v. 38, p. 1047-1416, doi:10.1002/esp.3389.

Wohl, E., Kuzma, J., and Brown, N., 2004, Reach-scale channel geometry of a mountain river: Earth Surface Processes and Landforms, v. 29, p. 969-981, doi:10.1002/esp.1078.

Wohl, E., et al., 2017, Mapping longitudinal stream connectivity in the North St. Vrain Creek watershed of Colorado: Geomorphology, v. 277, p. 171-181, doi:10.1016/j.geomorph.2016.05.004. 
Publisher: GSA

Journal: GEOL: Geology

DOI:10.1130/G38935.1

Yochum, S., 2015, September 2013 Colorado Front Range flood: Peak flows, flood frequencies, and impacts: Proceedings, 3rd Joint Federal Interagency Conference on Sedimentation and Hydrologic Modeling, p. 537-548, https://acwi.gov/sos/pubs/3rdJFIC/Contents/3F-Yochum.pdf.

\section{FIGURE CAPTIONS}

Figure 1. Flood impacts in the North St. Vrain Creek catchment, northern Colorado, USA. A: Catchment location, topography, and study sites with respect to total flood rainfall and landslides. B: Digital elevation model of difference (DoD) between pre-flood and post-flood lidar for the study reach highlighted in A. C: DoD showing extensive flood deposition in the reservoir inlet, forming a new approach channel. Vertical change in range of red to blue, and horizontal scale in C, applies to B and C. D: Reservoir inlet shown in C. Images in D and E are from Google Earth ${ }^{\mathrm{TM}}$. E: Locations of a large log jam formed during the flood, new approach channel, and reservoir delta cores.

Figure 2. Flood and post-flood sediment, carbon, and wood flux diagram for the North St. Vrain Creek catchment, Colorado, USA. Pie diagrams represent organic carbon as soil, litter, and wood, and illustrated wood jams represent volumes of large wood. Colors of boxes, arrows, and text are consistent for sediment (tan) and wood (brown), with pie diagram colors for soil (gray), litter (dark gray), and wood (black) as carbon. The sediment flux component is based on Fryirs and Brierley (2001).

Figure 3. Associations between flood sediment aggradation, channel widening, processes of bend adjustment and avulsion, and potential log jams along North St. Vrain Creek, 
Publisher: GSA

Journal: GEOL: Geology

DOI:10.1130/G38935.1

Colorado, USA. Channel-width change was measured as the difference between pre-

flood and post-flood channel corridor (see Fig. 1B) at $20 \mathrm{~m}$ increments averaged by 100

$\mathrm{m}$ reach compared to sediment aggradation. Marker size is proportional to sediment

availability calculated as the cumulative net change downstream. 